\title{
KESENJANGAN PERTUMBUHAN EKONOMI DI PROVINSI MALUKU
}

\section{ECONOMIC GROWTH IMBALANCE IN MOLUCCAS PROVINCE}

\author{
Zakarias Lamere \\ Jen Tatuh \\ Gene G. H, Kapantow
}

\begin{abstract}
This research is belongs to execute economic growth place clasification in Regency/City of Moluccas Province and to analysis economic imbalance in Moluccas Province. Analysis methood in this research use Klassen Typology, Williamson Index and Panel Data. Klassen Typology Analysis are use to vote the clasification of economic growth in every regency/city at Moluccas Provincy. Williamson Index Analysis are use to count economic imbalance rate in Moluccas Provincy. Panel Data is a bundle or a collected from time series (2006 - 2010) and data cross section (11 Regency/City), use to see many factors that made imbalance development in Moluccas Province. Klassen Typology Analysis research shown that just one area where looking forward and growth, it is Ambon City. Category area where looking suppressed in the develop process is Tual City, and prosperous area where are in down is Aru Regency, Centre Moluccas Regency, East Seram Regency, West Seram Regency, South Buru regency, S.W Moluccas Regency, S.E.W Moluccas Regency, Buru Regency, and South East Moluccas Regency. For Moluccas Province, Williamson Index in 2006 2010 scored at a stretch is 0,$5833 ; 0,5660 ; 0,6294 ; 0,5883 ; 0,5286$. It indicates that there is a high imbalance of economic growth. Outcome panel data analysis shown that imbalance development that rate by IPM showed $\alpha=5$ percent in real by economic growth, work force growth, long road regency and real in $\alpha=10$ percent by long road province. To anticipate the imbalance in Moluccas Province that must have work force quality, high performance, and usefull for upgrading income per capita and economic growth, and so centre of economic growth must be explore to every regency/city so that economic activity not constructed at one area.
\end{abstract}

Keyword : Economic Growth, Imbalance, Klassen Typology, Panel Data.

\section{ABSTRAK}

Penelitian ini bertujuan untuk menentukan klasifikasi wilayah pertumbuhan ekonomi Kabupaten/Kota di Provinsi Maluku dan menganalisis kesenjangan pertumbuhan ekonomi di Provinsi Maluku. Metode analisis yang digunakan ialah analisis Tipologi Klassen, Indeks Williamson, dan Data Panel. Analisis Tipologi Klassen digunakan untuk menentukan klasifikasi wilayah pertumbuhan ekonomi kabupaten/kota di Provinsi Maluku. Analisis Indeks Williamson digunakan untuk menghitung tingkat ketimpangan pembangunan ekonomi di Provinsi Maluku. Analisis Data Panel yang merupakan gabungan dari time series $(2006$ - 2010) dan data cross section (11 Kabupaten/Kota), digunakan untuk melihat faktor-faktor yang berpengaruh dalam terjadinya kesenjangan pembangunan di Provinsi Maluku. Hasil Analisis Tipologi Klassen menunjukkan bahwa daerah yang mengalami cepat maju dan cepat tumbuh hanya satu daerah yakni Kota Ambon. Daerah yang dikategorikan tertekan dalam proses membangun ialah Kota Tual, dan daerah makmur yang sedang menurun ialah Kabupaten Aru, Kabupaten Maluku Tengah, Kabupaten Seram Bagian Timur, Kabupaten Seram bagian Barat, Kabupaten Buru Selatan, Kabupaten Maluku Barat Daya, Kabupaten Maluku Tenggara Barat, Kabupaten Buru, dan Kabupaten Maluku Tenggara. Untuk Provinsi Maluku Indeks Williamson tahun 2006 - 2010 berturut-turut sebesar 0,5833; 0,5660; 0,6294; 0,5883; 0,5286. Ini mengindikasikan adanya ketimpangan tinggi dalam pertumbuhan ekonomi. Hasil analisis data panel menunjukkan bahwa kesenjangan pembangunan yang diukur dengan IPM dipengaruhi nyata pada $\alpha=5$ persen oleh laju pertumbuhan ekonomi, laju pertumbuhan angkatan kerja dan panjang jalan kabupaten, dan nyata 
pada $\alpha=10$ persen oleh panjang jalan provinsi. Guna mengantisipasi kesenjangan yang terjadi di Provinsi Maluku maka perlu adanya kualitas angkatan kerja yang unggul, trampil, dan dapat diandalkan sebagai upaya peningkatan pendapatan per kapita dan peningkatan pertumbuhan ekonomi, diperlukan penyebaran pusat-pusat pertumbuhan ekonomi ke kabupaten/kota sehingga kegiatan ekonomi tidak terkonsentrasi di satu titik.

Kata Kunci: Kesenjangan, Pertumbuhan Ekonomi, Tipologi Klassen, Data Panel

\section{PENDAHULUAN}

\section{Latar Belakang}

Pembangunan adalah proses natural mewujudkan cita-cita bernegara, yaitu terwujudnya masyrakat mekmur sejahtera secara adil dan merata. Kesejahteraan ditandai dengan kemakmuran yaitu meningkatnya konsumsi disebabkan meningkatnya penda-patan (Sumodiningrat, 2001). Hal senada juga diungkapkan oleh Todaro (2010) bahwa pembangunan adalah proses multidi-mensional yang melibatkan perubahan-perubahan mendasar dalam struktur sosial, perilaku sosial, dan institusi nasional, disamping akselerasi pertumbuhan ekonomi, pengurapan ketidakmerataan, dan pembe-rantasan kemiskinan.

Maluku sebagai salah satu provinsi yang berada di Kawasan Timur Indonesia, memiliki karakteristik yang berbeda dengan provinsi lain baik di Kawasan Barat Indonesia, maupun di Kawasan Timur Indonesia. Salah satu perbedaannya yaitu realitas pembangunan pasca konflik sosial di Maluku yang cukup menciptakan kesenjangan pembangunan antar Kabupaten/Kota di Maluku.

Persoalannya bahwa bagaimana pemerintah Daerah Provinsi Maluku berupaya mengabsorsi dana perimbangan keuangan pusat, untuk dimanfaatkan baik dalam mengejar pertumbuhan maupun dalam mengatasi kesenjangan pembangunan di Provinsi Maluku. Setiap Kabupaten/Kota di Provinsi Maluku memiliki potensi wilayah yang berbeda. Potensi wilayah yang berbeda ini mengakibatkan pertumbuhan ekonomi yang berbeda pula. Ada daerah yang cepat berkembang dan yang lambat berkembang. Perbedaaan pertumbuhan ekonomi ini menciptakan kesenjangan ekonomi.

\section{Kesenjangan dan Pertumbuhan Ekonomi antar Daerah}

\section{Kesenjangan}

Secara teoritis, permasalahan kesenjangan pembangunan antar wilayah mulamula dimunculkan oleh Douglas C. North dalam analisisnya tentang teori pertumbuhan Neoklasik. Dalam teori tersebut dimunculkan sebuah prediksi tentang hubungan antara tingkat pembangunan ekonomi nasional suatu negara dengan kesenjangan pembangunan antar wilayah. Hipotesa ini kemudian lazim dikenal sebagai Hipotesa Neo-klasik (Sjafrizal, 2008).

Menurut hipotesa Neo-klasik pada permulaan proses pembangunan suatu negara, kesenjangan pembangunan antar wilayah senderung meningkat. Proses ini akan terjadi sampai kesenjangan tersebut mencapai titik puncak. Setelah itu bila proses pembangunan terus berlanjut, maka secara berangsur-angsur kesenjangan pembangunan antar wilayah berbentuk huruf " $\mathrm{U}$ " terbalik Reverse U-Shape Curve).

\section{Pertumbuhan Ekonomi}

Pertumbuhaan ekonomi merupakan perubahan tingkat kegiatan ekonomi yang berlangsung dari tahun ke tahun. Untuk mengetahui tingkat pertumbuhan ekonomi harus membandingkan angka pendapatan nasional yang dihitung berdasarkan nilai riil. Perubahan pendapatan nasional hanya sematamata disebabkan oleh perubahan dalam tingkat kegiatan ekonomi atau dengan kata lain pertumbuhan baru tercapai apabila jumlah barang dan jasa yang dihasilkan bertambah besar pada tahun berikutnya. Untuk mengetahui apakah perekonomian mengalami pertumbuhan, harus dibedakan PDRB riil satu 
tahun dengan PDRB riil tahun sebelumnya (Sadono Sukirno, 2010).

Suatu perekonomian dikatakan mengalami pertumbuhan atau perkembangan jika tingkat kegiatan ekonomi meningkat atau lebih tinggi jika dibandingkan dengan tahun sebelumnya. Dengan kata lain, perkembangannya baru terjadi jika jumlah barang dan jasa secara fisik yang dihasilkan perekonomian tersebut bertambah besar pada tahun-tahun berikutnya. Indikator keberhasilan pembangunan ekonomi suatu daerah dapat ditunjukan oleh pertumbuhan ekonomi. Pertumbuhan ekonomi adalah pertumbuhan pendapatan masyarakat secara keseluruhan sebagai cermin kenaikan seluruh nilai tambah yang tercipta di suatu wilayah (Lincolin Arsyad, 1999).

\section{Pertumbuhan Ekonomi Regional}

Menurut Glasson (Irawan dan Suparmoko, 2008) pertumbuhan regional dapat terjadi sebagai akibat dari penentu-penentu endogen ataupun eksogen, yaitu faktor-faktor yang terdapat di dalam daerah yang bersangkutan ataupun faktor-faktor di luar daerah, atau kombinasi dari keduanya. Penentu endogen, meliputi distribusi faktor-faktor produksi seperti tanah, tenaga kerja, dan modal sedangkan penetu eksogen adalah tingkat permintaan dari daerah lain terhadap komoditi yang dihasilkan oleh daerah tersebut.

\section{Pertumbuhan Ekonomi dan Kesenjangan}

Menurut Puslitbang Ekobank, LIPI, 1994 (Kuncoro 2010) teori pertumbuhan ekonomi dan ketimpangan dapat dijelaskan sebagai berikut :

1. Para ekonomi klasik (Roberti, 1974), Hayani dan Ruffan (1985), mengemukakan pertumbuhan ekonomi akan selalu cenderung mengurangi kemiskinan dan ketimpangan pendapatan walaupun masih dalam tahap awal pertumbuhan. Bukti empiris dari pandangan ini berdasarkan pengamatan dibeberapa negara seperti ; Taiwan, Hongkong, Singapura, RCC, Kelompok Neo-klasik sangat optimis bahwa pertumbuhan ekonomi pada prakteknya cenderung mengurangi ketimpangan pendapatan dan kemiskinan.
2. Neo Marxist menyatakan bahwa pertumbuhan ekonomi justru akan selalu menyebabkan melebarnya jurang ketimpangan atara si kaya dan si miskin. Hal ini terjadi karena adanya akumulasi modal dan kemajuan tegnologi yang cenderung meningkatkan konsentrasi penguasaan sumber daya dan kapital oleh para penguasa modal kelompok "elit" masyarakat. Sebaliknya non pemilik modal akan tetap berada dalam keadaan kemiskinan.

\section{Kesenjangan Pertumbuhan Ekonomi antar Daerah}

Menurut Williamson, pada umumnya Regional Inqualities cenderung membesar, pada saat terjadinya proses perkembangan. Hal ini disebkan karena ;

a. Migrasi penduduk yang produktif (usia kerja) dan memiliki keahlian (terdidik) dari daerah-daerah kurang berkembang ke daerah-daerah yang telah berkembang, karena di sana mereka dapat memperoleh upah/gaji yang lebih besar.

b. Investasi cenderung dilakukan di daerah yang telah berkembang karena faktor pasar (skala ekonomi, ekonomi eksternal, dan lain sebagainya), dimana keuntungannya relatif besar, demikian pula resiko kerugian relatif kecil pada umumnya. Disamping itu, terjadi pula pengaliran modal dari daerah miskin menuju daerah yang telah berkembang.

c. Kebijakan pemerintah, didasari atau tidak cenderung mengakibatkan terkonsentrasinya saran dan prasarana kegiatan sosial ekonomi di daerah yang telah berkembang karena adanya kebutuhan yang lebih besar. Hal ini justru telah mendorong perkembangan industri yang lebih pesat di daerah yang lebih maju.

d. Pola perdagangan dan kegiatan perdagangan didominasi oleh industri-industri di daerah yang telah berkembang. Industri di daerah yang kaya telah menjadi sumber dari barang-barang yang diperdagangkan, dan demikian industri yang dikembangkan di daerah miskin akan mengalami banyak kesulitan dalam memperoleh pasarnya. Ketidaksanggupan untuk bersaing industri di daerah yang lebih maju menjadi lebuh serius lagi keadaannya sebagai akibat dari 
buruknya jaringan perangkutan dan prasarana ekonomi lainnya di daerah yang lebih miskin (Arsyad Lincolin, 2010).

\section{Rumusan Masalah}

Kesenjangan merupakan suatu tolak ukur pelaksanaan perencanaan pembangunan ekonomi sehingga diperlukan analisa pengaruh ditinjau dari karakteristik regional guna mewujudkan eksistensi perekonomian di Provinsi Maluku. Adapun karakteristik yang mempengaruhi kesenjangan di Provinsi Maluku ialah pertumbuhan indeks pembangunan manusia, laju pertumbuhan ekonomi, dana alokasi umum, laju angkatan kerja, panjang jalan nasional, Provinsi dan Kabupaten. Bertolak dari penjelasan tersebut, maka perlu diketahui gambaran klasifikasi wilayah pertumbuhan ekonomi Kabupaten/Kota di Provinsi Maluku dan seberapa besar tingkat kesenjangan pertumbuhan ekonomi antar Kabupaten/Kota di Provinsi Maluku serta bagaimana laju pertumbuhan indeks pembangunan manusia, laju pertumbuhan ekonomi, dana alokasi umum, laju angkatan kerja panjang jalan nasional, Provinsi, dan Kabupaten terhadap kesenjangan di Provinsi Maluku ?

\section{Tujuan Penelitian}

Berdasarkan latar belakang dan rumusan masalah di atas, maka tujuan penelitian ini ialah untuk :
1. Menentukan
klasifikasi wilayah pertumbuhan ekonomi Kabupaten/Kota di Provinsi Maluku.

2. Menganalisis kesenjangan pertumbuhan ekonomi di Provinsi Maluku.

\section{Manfaat Penelitian}

Manfaat penelitian ini yakni memberikan sumbangan pemikiran kepada pemerintah Provinsi Maluku dan pemerintah Kabupaten/Kota di Provinsi Maluku tentang klasifikasi wilayah pertumbuhan ekonomi Daerah Kabupaten/Kota dan kesenjangan pertumbuhan ekonomi yang terjadi di Maluku dan pemerintah Kabupaten/Kota untuk memilih alternatif kebijakan yang akan diambil untuk mengurangi tingkat kesenjangan pertumbuhan ekonomi, serta memberikan tambahan acuan untuk peneliti berikutnya, khususnya penelitian yang berkaitan dengan masalah kesenjangan pertumbuhan ekonomi wilayah.

\section{METODE PENELITIAN}

\section{Tempat dan Waktu Penelitian}

Penelitian ini dilakukan pada Provinsi Maluku, dimulai padas bulan April sampai Juli 2012.

\section{Metode dan Pengumpulan Data}

Teknik pengumpulan data menggunakan metode dokumentasi yaitu data yang diperoleh dari buku, laporan, website dan penerbitan lainnya. Data yang digunakan dalam penelitian ini ialah data sekunder.

\section{Definisi Operasional Variabel}

Memberikan kesamaan pemahaman terhadap variabel independen, ataupun variabel dependen dalam penelitian kesenjangan pertumbuhan ekonomi di Provinsi Maluku, maka diperlukan suatu definisi operasional variabel, yakni :

\section{a. Indeks Ketimpangan Pembangunan Ekonomi}

Ketimpangan pembangunan ekonomi diukur dengan menggunakan rumus indeks Williamson, dimana pendapatan diukur dengan menggunakan rumus indeks kapita atas dasar harga konstan untuk setiap Kabupaten/Kota di Provinsi Maluku dari tahun 2006-2010

b. Indeks Pembangunan Manusia Indeks Pembangunan Manusia (IPM) menurut Badan Pusat Statistik (BPS, 2011) merupakan indikator komposit tunggal yang digunakan untuk mengukur pencapaian pembangunan manusia yang telah dilakukan di suatu wilayah (dalam satuan persen).

c. Pertumbuhan Ekonomi

Pertumbuhan Ekonomi menunjukkan tingkat pertumbuhan agregat pendapatan untuk masing-masing tahun dibandingkan tahun sebelumnya (BPS, 2011. Variabel pertumbuhan ekonomi ialah dalam persen. 


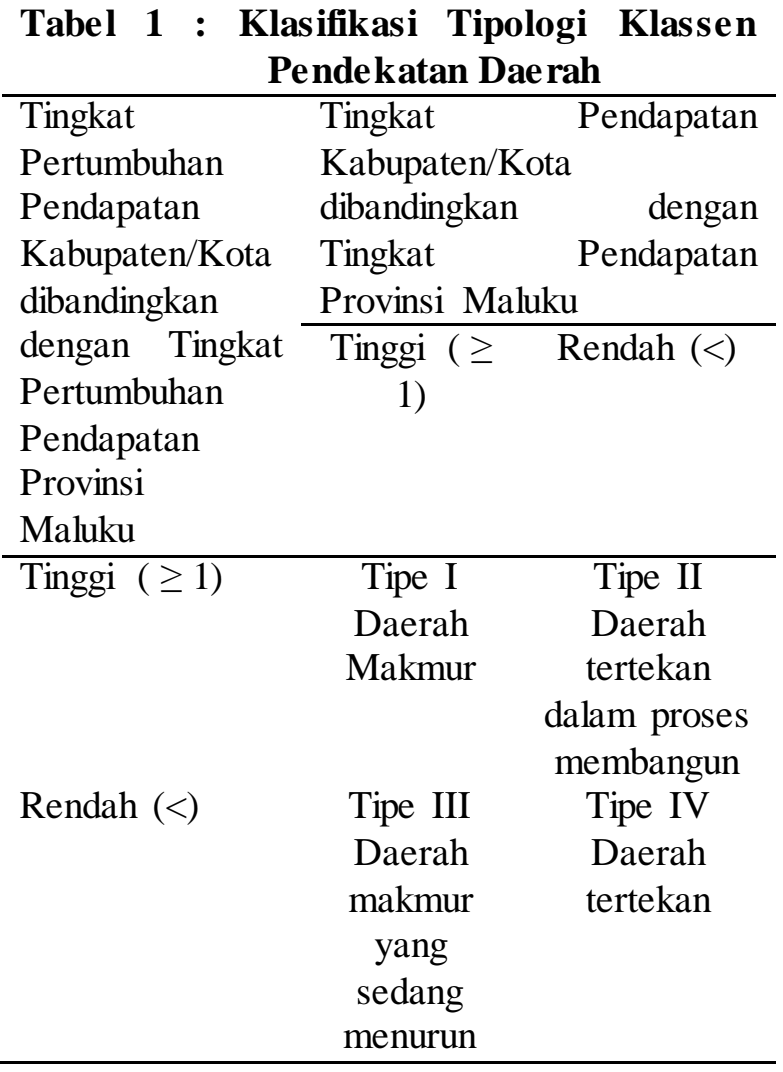

d. Dana Alokasi Umum

Dana Alokasi Umum adalah dana yang bersumber dari penerimaan Anggaran Pendapatan dan Belanja Negara yang dialokasikan kepada daerah (dalam satuan persen).

e. Laju Pertumbuhan Angkatan Kerja Penduduk usia 15 tahun ke atas yang aktif dalam kegiatan ekonomi, yaitu jumlah penduduk yang bekerja dan yang belum bekerja atau yang sedang mencari pekerjaan pada suatu wilayah dalam jangka waktu tertentu. Variabel laju pertumbuhan angkatan kerja ialah dalam persen.

f.

g. Panjang Jalan

Di dalam penelitian ini data jalan yang digunakan adalah total panjang jalan Nasional, Provinsi, dan Kabupaten/Kota. Variabel panjang jalan ialah dalam kilo meter.

\section{Metode Analisis Data}

Analisis data menggunakan tiga alat analisis yaitu: Klasifikasi Wilayah, Analisis Ketimpangan Pertumbuhan Ekonomi dan Analisis Panel Data.

\section{Klasifikasi Wilayah}

Analisis yang digunakan untuk mengetahui gambaran tentang klasifikasi wilayah pertumbuhan ekonomi masing-masing daerah ialah Analisis Tipologi Klassen (Kuncoro, 2010). Kriteria yang digunakan terdiri atas empat kuadran/klasifikasi. Pendekatan dalam Tipologi Klassen ialah pendekatan daerah seperti yang diutarakan oleh Arsyad Lincolin (2010).

2. Analisis Ketimpangan Pertumbuhan Ekonomi

Memberikan gambaran yang lebih baik tentang perkembangan masing-masing daerah dari segi pemerataan pembangunan, dapat diamati dengan menggunakan indeks ketimpangan pembangunan antar daerah yang semula dipergunakan oleh Jeffrey G. Williamson., perhitungan Indeks Williamson didasarkan pada data PDRB masing-masing daerah dengan menggunakan rumus sebagai berikut (Kuncoro, 2002) :

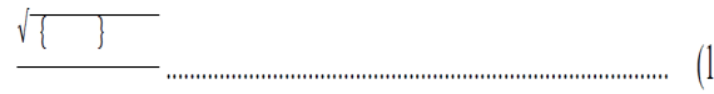

$\begin{array}{ll}\text { Keterangan } & : \\ \text { IW } & : \text { Nilai Indeks } \\ & \text { Williamson } \\ \mathrm{Yi} & : \text { Pendapatan per kapita } \\ & \text { masing-masing } \\ & \text { Kabupaten/Kota i } \\ & : \text { Pendapatan per kapita } \\ & \text { rata-rata Provinsi } \\ & \text { Maluku } \\ & : \text { Jumlah penduduk } \\ & \text { masing-masing } \\ \mathrm{Ni} & \text { Kabupaten/Kota } \\ & : \text { Jumlah penduduk } \\ & \text { rovinsi Maluku }\end{array}$

Hasil pengujian Indeks Williamson akan menunjukkan nilai antara 0 sampai 1 . Semakin besar nilai Indeks Williamson, maka semakin besar ketidakmerataan antar daerah dan sebaliknya semakin kecil nilai Indeks Williamson, maka tingkat ketidak- merataan antar daerah semakin kecil.

Oshima (Sutawijaya, 2004) me-netapkan sebuah kriteria yang di-gunakan untuk menentukan apakah ketimpangan taraf rendah, 
sedang, atau tinggi. Ditentukan beberapa kriteria yang ada sebagai berikut :

a. Ketimpangan taraf rendah bila Indeks Williams on $<0,35$;

b. Ketimpangan taraf sedang bila Indeks Williams on antara $0,35-0,50$; dan

c. Ketimpangan taraf tinggi bila Indeks Williams on >0,50

Teknik analisis ini digunakan untuk mengetahui sebarab distribusi ketim-pangan pendapatan di Provinsi Maluku.

\section{Data Panel}

Analisis panel data adalah metode yang menjelaskan gabungan data antar waktu (timeseries) dengan data antar individu (crosssection). Data (cross-section) merupakan data yang dikumpulkan dalam satu waktu terhadap banyak individu. Sedangkan data (time-series) adalah data yang dikumpulkan dari waktu ke waktu terhadap satu individu. Data yang dikumpulkan secara (cross-section) dan diikuti pada periode waktu tertentu tersebut dikenal dengan nama data panel. (Rosandi Dedi, 2011 dan 2012).

Mengingat data panel merupakan gabungan dari data cross-section dan timeseries, maka modelnya dituliskan dengan :

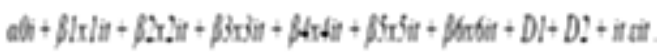

$\begin{array}{ll}\text { Keterangan } & : \\ \mathrm{Y} & : \text { Indeks Pembangunan } \\ & \text { Manusia } \\ \mathrm{I} & : \text { Kabupaten/Kota } \\ & (1, \ldots 11) / \text { cross section } \\ & : \text { Waktu (tahun } \\ & 2006, \ldots . .2010) / \text { time } \\ \mathrm{T} & \text { series } \\ & : \text { Konstanta/koofisien } \\ & \text { intersep } \\ \mathrm{A} & : \text { Laju Pertumbuhan } \\ & \text { Ekonomi } \\ \mathrm{X} 1 & : \text { Dana Alokasi Umum } \\ & : \text { Laju Pertumbuhan } \\ \mathrm{X} 2 & \text { Angkatan Kerja } \\ \mathrm{X} 3 & \end{array}$

$\mathrm{X} 4$

$\mathrm{X} 5$

$\mathrm{X} 6$

D1

$\dot{\varepsilon}$

$\beta 1, \beta 2, \beta 3, \beta 4, \beta 5, \beta 6$

(




\section{HASIL DAN PEMBAHASAN}

\section{Klasifikasi Wilayah Pertumbuhan Ekonomi Kabupaten/Kota di Provinsi Maluku}

Pertumbuhan ekonomi di Provinsi Maluku selama tahun 2006-2010 mengalami peningkatan, yakni rata-rata pertumbuhan sebesar 5,51 persen. Kabupaten/Kota yang tertingi diatas rata-rata pertumbuhan ekonomi Provinsi Maluku adalah Kota Ambon, yakni sebesar 5,92 persen dan Kota Tual, yakni Sebesar 5,67 persen. Sementara Aru dan Maluku Tengah mengalami rata-rata Pertumbuhan sebesar 5,43persen dan 5,17 persen. Sedangkan Seram Bagian Timur, Buru Selatan, Maluku Barat Daya dan Sera Bagian Barat mengalami Pertumbuhan berkisar 4,00 persen sampai dengan 4,99 persen.

Dari Gambar 1 dapat diketahui bahwa daerah yang mengalami cepat maju Dan cepat tumbuh (high growth and high income) ialah Kota Ambon. Kota Kota Tual berada pada kuadran daerah maju tapi tertekan. Sedangkan 9 kabupaten Lainnya berada pada kuadran daerah berkembang cepat tetapi pertumbuhannya lambat. Pertumbuhan ekonomi yang tinggi dapat dilihat dari pesatnya pembangunan infrastruktur yang ada di Kota Ambon dan Kota Tual yang mengindikasikan besarnya investasi yang masuk. Banyaknya investasi yang ada menawarkan berbagai peluang kerja dengan tingkat pendapatan yang lebih baik, sehingga pendapatan perkapita tinggi.

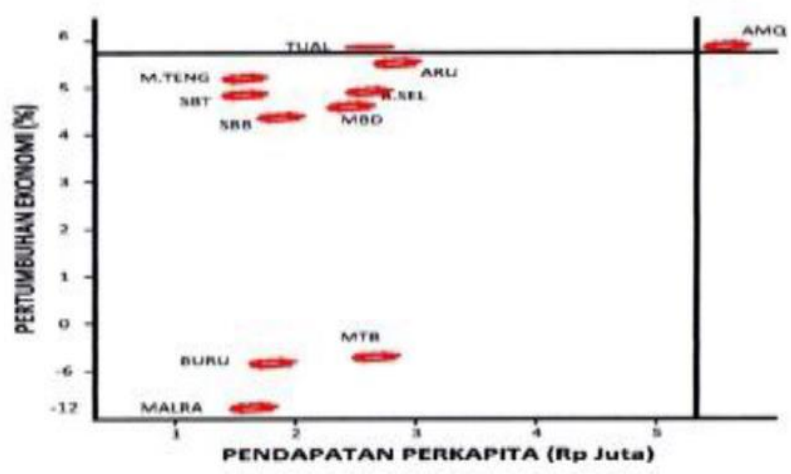

Sumber : data diolah

Gambar 1 Klasifikasi Wilayah di Provinsi Maluku Tahun 2006-2010

Kota Ambon berada pada kuadran cepat maju dan cepat tumbuh disebabkan oleh beberapa faktor, yakni Kota Ambon sebagai pusat Pemerintahan Provinsi Maluku secara langsung berpengaruh pada peningkatan PDRB. Sebagai pusat pemerintahan, Kota Ambon mendapat keuntungan dengan alokasi jasa pemerintahan yang lebih besar dibandingkan Kabupaten/Kota lainnya, pada tahun 2010 ada ivent internasional, yakni Seal Banda. Setahun sebelum kegiatan tersebut dilaksanakan sektor bangunan mendapat Kontribusi besar dan pada saat kegiatan tersebut dilaksanakan sektor Perdagangan, Hotel, dan Restoran mendapatkan kenaikan kontribusi yang besar, dan Kota Ambon juga menjadi pusat kegiatan ekonomi di Provinsi Maluku. Kabupaten/Kota yang dapat dikategorikan ke dalam daerah yang maju tapi Tertekan (high income but low growth) ialah KotaTual. PDRB yang tinggi dapat Dilihat dari pesatnya pembangunan infrastruktur dan banyaknya investasi baik itu Dari pemerintah maupun swasta. Dari segi pemerintahan Kota Tual baru dimekarkan, sehingga dari segi alokasi anggaran mendapat perhatian lebih guna membenahi sarana dan prasarana, dan Kota Tual dalam Rencana Tata Ruang Wilayah Provinsi Maluku ditetapkan sebagai pusat industri ikan terbesar di Provinsi Maluku. Daerah yang dapat dikategorikan berkembang cepat dalam arti Pertumbuhan (high growth but low income) ialah Aru, Maluku Tengah, Seram Bagian Timur, Buru Selatan, Seram Bagian Barat, Maluku Tenggara Barat, Buru, dan Maluku Tenggara. Daerah-daerah tersebut diatas mempunyai pendapatan tinggi tapi pertumbuhannya rendah dikarenakan oleh :

Daerah-daerah tersebut dapat dikategorikan berkembang cepat dalam arti pertumbuhan (high growth but low income) ialah Aru, Maluku Tengah, Seram Bagian Timur, Buru Selatan, Seram Bagian Barat, Maluku Tenggara Barat, Buru, dan Maluku Tenggara.

1. Dilihat dari segi pendapatan per kapita, merupakan daerah dengan tingkat pendapatan per kapita yang lebih kecil dibandingkan dengan Kota Ambon.Total PDRB 9 Kabupaten tersebut tidak seimbang dengan jumlah penduduk. Artinya, bahwa jumlah penduduk tidak memberikan kontribusi positif dalam pembangunan 
wilayah, bahkan menjadi beban bagi penduduk lainnya.

2. Faktor Pemekaran Daerah. Fenomena daerah yang baru dimekarkan (Maluku Barat Daya, Kota Tual, dan Buru Selatan) mengalami pertumbuhan rata-rata diatas Kabupateninduk (Maluku Tenggara Barat, Maluku Tenggara, dan Buru).

3. Keterbatasan pengangkutan dan komunikasi yang berdampak pada kurang lancarnya perdagangan antar daerah. Maluku sebagai Provinsi Kepulauan lebih mengandalkan Sektor Pertanian sebagai sector penyumbang terbesar bagi PDRB tidak diimbangi dengan ketersediaan Sektor Pengangkutan dan Komunikasi yang mamadai. Setiap tahun di perairan Maluku selalu terjadi kecelakaan laut yang menelan korban jiwa dan harta.

4. Factor backwash effect mendominasi spread effect. Daya tarik pada daerah yang lebih maju akan menyebabkan akumulasi keunggulan kompetitif dibandingkan daerah lain.

Upaya untuk meningkatkan pertumbuhan ekonomi (high growth) dan pendapatan per kapita (high income) pada Kabupaten tergolong daerah makmur yang sedang menurun dapat dilakukan dengan cara :

1. Sektor Pertanian menjadi leading dalam hal kontribusinya terhadap PDRB Provinsi maupun Kabupaten. Perlu mengubah strategi pertanian dari sistem monokultur ke sistem diversivikasi pertanian. Sub-sektor perikanan juga merupakan penyumbang terbesar bagi PDRB Kabupaten. Budidaya perikanan dan perikanan tangkap perlu dikembangkan terus-menerus sebagai usaha untuk menjawab kebijakan nasional yang menetapkan Provinsi Maluku sebagai Lumbung Ikan Nasional. Revitalisasi ini harus ditopang dengan peningkatan ketrampilan, pemodalan, transportasi dan pasar.

2. Perbaikan saran dan prasarana pengangkutan dan komunikasi, khususnya angkutan laut. Sektor ini perlu diperhatikan dengan baik, agar tidak terjadi illegal fishing mengingat secara geografis berbatasan dengan Negara Australia. Transportasi laut menjadi kendala utama bagi pelaksanaan pembangunan mengingat Kabupaten ini merupakan Kabupaten Kepulauan.
3. Memanfaatkan dampak sebar (spread effect), arti sebagai daerah yang mempunyai bahan mentah bagi daerah yang lebih maju terlebih hasil pertanian.

\section{Ketimpangan Pertumbuhan Ekonomi Provinsi Maluku}

Berdasarkan hasil perhitungan dengan Indeks Williamson, dapat dikategorikan bahwa tingkat ketimpangan di Provinsi Maluku selama tahun 2006 - 2010 mengalami fluktuasi, rata-rata kesenjangan sebesar 0,5879. Kesenjangan mengalami fluktuasi disebabkan oleh :

1. Perbedaan besaran nilai investasi yang masuk ke masing-masing Kabuoaten/Kota berdampak pada tingkat pertumbuhan wilayah. Pada tahun 2010 di Provinsi Maluku dilaksanakan Seal Banda yang investasinya berpusat di Kota Ambon dan Kabupaten Maluku Tengah.

2. Sarana prasarana pengangkutan dan komunikasi yang belum merata antar daearah mengakibatkan kurang lancarnya perdagangan. Provinsi Maluku sebagai Provinsi Kepulauan mempunyai sarana transportasi laut masih kurang sehingga berpengaruh pada penjualan hasil pertanian belum berjalan dengan efisien dan masih maraknya illegal fishing di perairan Maluku.

3. Dampak balik (backwash effect) merupakan faktor penentu bagi penduduk untuk bermigrasi ke daerah yang lebih maju sehingga akan menyebabkan akumulasi keunggulan kompetitif dibandingkan daerah lain.

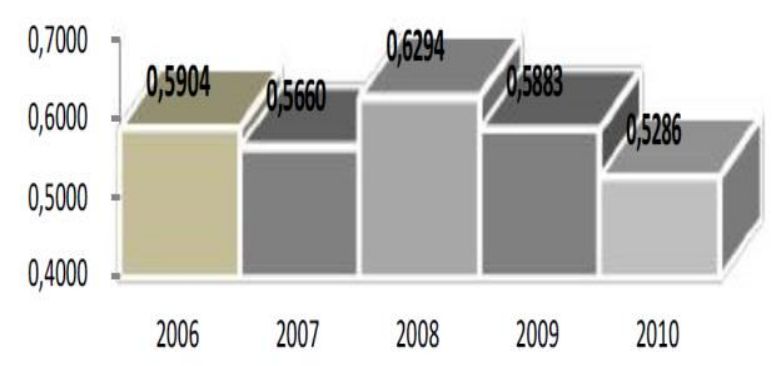

Gambar 2 Indeks Williamson Provinsi Maluku Tahun 2006 - 2010 
Berdasarkan kriteria Oshima, ketimpangan pertumbuhan ekonomi di Provinsi Maluku berada pada taraf tinggi. Untuk lebih jelasnya dapat dilihat pada Gambar 5 mengenai Indeks Williams on.

Tingkat kesenjangan pembangunan yang tinggi akan menimbulkan kecemburuan antar daerah, guna mengurangi tingkat kesenjangan dapat dilakukan beberapa upaya yakni :

1. Menetapkan Upah Minimum Provinsi (UMP) yang pro poor serta melakukan pengawasan ketat terhadap kebijakan tersebut. Diharapkan dengan adanya UMP yang pro poor akan memperkecil perbedaaan per kapita antar daerah.

2. Menetapkan daerah konsentrasi kegiatan ekonomi baru pada wilayah tertinggal berupa aglomerasi sector pertanian.

3. Perbaikan sarana dan prasarana pengangkutan dan komunikasi serta infrastruktur penunjang investasi di wilayah tertinggal melalui alokasi dana bantuan pemerintah.

4. Memanfaatkan daya sebar (spread effect) daerah maju kemudian dijadikan sebagai suatu peluang bagi daerah tertinggal untuk menembangkan potensi sumber daya alamnya sebagai penyedia bahan baku mentah bagi daerah maju.

5. Memberikan jaminan keamanan bagi masyarakat agar dalam menjalankan aktifitas tidak ada rasa takut. Hal ini juga sangat berpengaruh kepada minat investor yang ingin menanamkan modalnya di Provinsi Maluku.

Nilai $R^{2}$ ialah 80,4 artinya bahwa sebesar 80,4 persen variabel IPM bias dijelaskan oleh variabel laju pertumbuhan ekonomi, dana alokasi umum, laju angkatan kerja, dan panjang jalan Provinsi dan Kabupaten. Sedangkan sisanya sebesar 19,96 persen bisan dijelaskan oleh variabel lain di luar model. Pada Tabel 3 Anova, terlihat nilai F hitung $(28=7,529)$ lebih besar dari pada nilai $\mathrm{F}$ tabel $(2,212)$ dan nilai Sig $0,000<0,005$. Modelnya dinyatakan cocok atau persamaan regresi yang terbentuk mampu menggambarkan keadaan yang sesungguhnya.

Variabel laju pertumbuhan ekonomi berpengaruh signifikan secara negatif, hali ini mengindikasikan kecendrungan bahwa laju pertumbuhan ekonomi memiliki hubungan negatif dengan IPM.

$$
\text { Variabel DAU berpengaruh tidak }
$$

signifikan secara negatif, hal ini mengindikasikan kecendrungan bahwa DAU memiliki hubungan negatif dengan IPM.

Variabel laju pertumbuhan angkatan kerja berpengaruh signifikan secara negatif, Variabel panjang jalan Kabupaten berpengaruh signifikan secara positif, jika variabel panjang jalan Kabupaten naik sebesar 1 unit (persen per tahun) akan menyebabkan meningkatnya IPM sebesar 0,029 unit (persen per tahun) cateris paribus.

hal ini mengindikasikan kecendrungan bahwa laju pertumbuhan angkatan kerja memiliki hubungan negatif dengan IPM.

\section{Data Panel}

1. Uji Signifikansi Model Regresi Data Panel Pada awalnya model yang akan digunakan adalah :

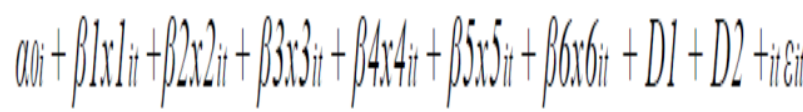

Namun setelah dilakukan pengujian terdapat asumsi-asumsi yang menyebabkan terjadinya multikolinieritas. Untuk mengarasi pelanggaran asumsi ini, variabel panjang jalan nasional dikeluarkan dari model. Setelah variabel tersebut dikeluarkan, diduga model regresi telah memenuhi asumsi-asumsi klasik. Hasil analisis regresi dapat dilihat pada Tabel 2.

\begin{tabular}{|c|c|c|c|c|c|}
\hline Model & $\overline{\mathbf{R}}$ & $\begin{array}{c}\mathbf{R} \\
\text { Squ- } \\
\text { are }\end{array}$ & $\begin{array}{c}\text { Adjus- } \\
\text { ted R }\end{array}$ & $\begin{array}{l}\text { Std. } \\
\text { Error } \\
\text { of the } \\
\text { Esti- } \\
\text { mate }\end{array}$ & $\begin{array}{l}\text { Durbin- } \\
\text { Watson }\end{array}$ \\
\hline 1 & $.897^{a}$ & $\begin{array}{l}.804 \\
\end{array}$ & .775 & 1.640 & 1.227 \\
\hline
\end{tabular}

2. Interpretasi Hasil Data Panel
a) Pengaruh Laju Pertunbuhan Ekonomi terhadap IPM

Berdasarkan hasil estimasi regresi berganda data panel, menunjukkan bahwa 
variabel laju pertumbuhan ekonomi berpengaruh signifikan secara negatif terhadap IPM di Provinsi Maluku pada tahu 2006-2010. Rata-rata laju pertumbuhan ekonomi di Provinsi Maluku selama periode pengamatan ialah sebesar 5,51 persen dan memiliki ratarata IPM sebesar 70,48 poin. Laju pertumbuhan ekonomi belum banyak membantu meningkatkan IPM karena kontribusi PDRB berjalan lambat. Rata-rata PDRB Provinsi Maluku tahun 2006-2010 ialah sebesar Rp392.732.810.000. laju pertumbuhan ekonomi berpengaruh signifikan secara negatif karena jumlah penduduk produktif banyak yang masih menggantungkan hidupnya pada masyarakat lainnya menjadi beban pembangunan.

b) Pengaruh Laju Pertumbuhan Angkatan Kerja terhadap IPM

Variabel ini berpengaruh signifikan secara negatif terhadap IPM karena di Provinsi Maluku persentase penduduk miskin sangat besar. Pada tahun 2010 jumlah penduduk miskin Kabupaten Maluku Barat Daya sebesar 39,28 persen. Jumlah tersebut sangat berbeda dengan Kota Ambon yang memiliki jumlah penduduk sebesar 7,67 persen. Jumlah tersebut dipengaruhi oleh kurang memadainya sumber daya manusia sehingga angkatan kerja yang bekerja di sektor informal seringkali tidak memiliki kesempatan untuk meningkatkan potensi dirinya sehingga menghapuskan prospek dalam memperoleh pekerjaan yang baik. Secara keseluruhan banyaknya pekerja usia muda ini karena pertumbuhan ekonomi tanpa lapangan pekerjaan yang memadai.

\section{c) Pengaruh Panjang Jalan terhadap IPM}

\section{Panjang Jalan Provinsi}

Berdasarkan hasil estimasi regresi berganda data panel, menunjukkan bahwa variabel panjang jalan nasional berpengaruh signifikan secara negatif terhadap IPM di Provinsi Maluku pada tahun 2006-2010.

\section{Panjang Jalan Kabupaten}

Berdasarkan hasil estimasi regresi berganda panel data, menunjukkan bahwa variabel Panjang Jalan Kabupaten berpengaruhi signifikan secara positif terhadap IPM di Provinsi Maluku pada tahun 20062010. Koefisien variabel dari Panjang Jalan Kabupaten ialah 0,0029 maka Panjang Jalan Kabupaten berpengaruh positif terhadap IPM di Provinsi Maluku. Jika Panjang Jalan Kabupaten naik 1 persen, maka IPM di Provinsi Maluku akan meningkat sebesar 0,029 persen. Panjang Jalan Kabupaten/Kota perlu ditambah setiap tahun anggaran membuka keterisolasian dan memberikan akses kepada masyarakat perdesaan guna bisa mendistribusikan hasil-hasil pertanian ke pasar bahkan sebaliknya.

\section{Pengaruh Dana Alokasi Umin terhadap IPM}

Berdasarkan hasil estimasi regresi berganda data panel, menunjukkan bahwa variabel DAU berpengaruhntidak signifikan secara negatif terhadap IPM di Provinsi Maluku pada tahun 2006-2010. Rata-rata DAU yang dialokasikan untuk pembiayaan pembangunan untuk masing-masing Kabupaten/Kota di Provinsi Maluku tahun 2006-2010 ialah sebesar Rp2.474.942.567.000. dari total anggaran tersebut lebih banyak anggaran digunakan untuk berbelanja pembangunan. Kontribusi DAU belum banyak membantu peningkatan IPM di Provinsi Maluku karena Maluku sebagai Provinsi Kepulauan yang memiliki luas wilayah $581.376 \mathrm{~km}^{2}$ (luas laut 527.191 $\mathrm{km}^{2}$ dan luas darat $\mathrm{km}^{2}$ ). Dari luas wilayah tersebut membutuhkan banyak anggaran untuk membangun Maluku. Provinsi Maluku dalam melaksanakan program pembangunan masih tergantung dengan pembiayaan dari pemerintah pusat. 
Tabel 3. Anova

\begin{tabular}{lccccc}
\hline Model & $\begin{array}{c}\text { Sum of } \\
\text { Squares }\end{array}$ & df & Mean Square & F & Sig. \\
\hline $1 \quad$ Regression & 518.078 & 7 & 74.011 & 27.529 & $.000^{a}$ \\
\cline { 3 - 4 } Residual & 126.359 & 47 & 2.688 & & \\
& & & & & \\
\hline \multicolumn{7}{c}{ Total } & & 644.436 & 54 & \\
\hline
\end{tabular}

Tabel 4. Coefficients

\begin{tabular}{lccccccc}
\hline \multicolumn{1}{c}{ Model } & \multicolumn{2}{c}{$\begin{array}{c}\text { Unstandardized } \\
\text { Coefficients }\end{array}$} & $\begin{array}{c}\text { Standartdized } \\
\text { Coefficients }\end{array}$ & $\mathrm{t}$ & Sig & \multicolumn{2}{c}{$\begin{array}{c}\text { Collienarity } \\
\text { Statistics }\end{array}$} \\
\cline { 2 - 8 } & $\mathrm{B}$ & $\begin{array}{c}\text { Std. } \\
\text { error }\end{array}$ & Beda & & & Tolenrance & VIF \\
\hline 1 (constant) & 78.507 & 1.245 & & & & & \\
Pertumbuhan & -036 & .017 & -170 & -2.118 & .040 & .694 & 1.540 \\
DAU & -159 & .098 & -187 & -1.616 & .113 & .310 & 3.226 \\
KERJA & -034 & .010 & -326 & -3.262 & .002 & .418 & 2.393 \\
D1 & -4.133 & 1.128 & -347 & -3.666 & .001 & .465 & 2.150 \\
D2 & -8.848 & .920 & -997 & -9.614 & .000 & .388 & 2.578 \\
J_PROVINSI & -022 & .011 & -275 & -1.947 & .058 & .209 & 4.792 \\
J_KABUPATEN & .029 & .010 & .539 & 2.760 & .008 & .109 & 9.143 \\
\hline
\end{tabular}

Sumber : Data diolah (Lampiran 18)

\section{KESIMPULAN DAN SARAN}

\section{Kesimpulan}

Berdasarkan hasil analisis kesenjangan pertumbuhan ekonomi di Provinsi Maluku terdapat

1. Klasifikasi wilayah pertumbuhan ekonomi di Provinsi Maluku bervariasi. Kota Ambon berada pada daerah makmur, Kota Tual berada pada daerah tertekan dalam proses pembangunan dan 9 Kabupaten lainnya berada pada daerah makmur yang sedang menurun.

2. Kesenjangan pembangunan di Provinsi Maluku (a) menurut Indeks Williamson berada dalam kategori tinggi karena pusat-pusat pertumbuhan ekonomi terkonsentrasi di Ibu Kota Provinsi Maluku yang berada di Kota Ambon, kurang memadainya sarana dan prasarana pengangkutan dan komunikasi serta infrastruktur penunjang investasi, dan faktor backwash effect merupakan faktor penentu bagi penduduk untuk berimigrasi ke daerah yang lebih maju sehingga menyebabkan akumulasi keunggulan kompetitif dibandingkan daerah lain. Migrasi penduduk ke daerah yang lebih maju ialah penduduk berpendidikan dan berketrampilan. Dampak spread effect yang kuat dan backwash effect yang lemah menyebabkan kesenjangan wilayah, dan (b) menurut Indeks Pembangunan Manusia variabel Laju Pertumbuhan Ekonomi, Dana Alokasi umum, Laju pertumbuhan Angkatan Kerja, Panjang Jalan Provinsi dan Panjang Jalan Kabupaten signifikan mempengaruhi indeks pembangunan manusia.

\section{Saran}

1. Kota Tual perlu mengembangkan sektor industri perikanan. Usaha ini akan memperkuat korelasi yang saling menguntungkan antara tenaga kerja dan perusahaan industri ikan dalam hal pengembangan nilai-nilai spesifik produk khususnya berkaitan dengan desain dan kualitas yang akan menambah daya tarik 
Kota Tual bagi konsumen di luar daerah. Sedangkan sembilan Kabupaten lainnya yang berada pada daerah makmur sedang menurun sedang perlu penetapan produk unggulan yang ditetapkan berdasarkan keunggulan komparatif yang menjadi produk ekspor utama yang dipasarkan ke lokasi lain. Dalam hal ini berlaku kondisi dimana daerah yang bersangkutan melakukan perdagangan untuk mencapai skala ekonomi dalam produksi. Artinya daerah tersebut dapat berkonsentrasi memproduksi komoditas unggulannya pada skala yang lebih besar sehingga lebih efisien dari pada harus memproduksi seluruh kebutuhan tanpa prioritas.

2. Perlu pemanfaatan daya sebar (spread effect) daerah maju kemudian dijadikan sebagai peluang bagi daerah tertekan dalam proses pembangunan dan daerah makmur yang sedang menurun untuk mengembangkan potensi sumber daya alamnya sebagai penyedia bahan baku mentah bagi daearah maju.

\section{DAFTAR PUSTAKA}

Arsyad, Lincolin. 2010. Pengantar Perencana an dan Pembangunan Ekonomi Daerah. (2 ed.). Yogyakarta: BPFEUGM. 1999. Ekonomi Pembangu -nan. Yogyakarta : STIE

BPS Maluku 2011. Pendapatan Regional Provinsi Maluku tahun 2010 Maluku dalam Angka.
Analisis Regional Provinsi Maluku menurut Kabupaten/Kota dan Gugus Pulau tahun 2010.

BPS RI, UNDP, Bappenas. 2005. Ekonomi dari Demokrasi : Membiayai Pembangunan Manusia Indonesia, Jakarta : Badan Pusat Statistik

Irawan dan Suparmoko. 2008. Ekonomi Pemb angunan. Edisi Keenam. Yogyakarta : BPFE-UGM.

Kluster Industri Indonesia. Yogyakarta : UUP AMP YKPN.

Kuncoro, Mudrajat. 2002. Analisis Spasial dan Regional : Studi Aglomerasi dan

Sjafrizal. 1997. Pertumbuhan Ekonomi dan Ketimpangan Regional Wilayah Indonesia Bagian Barat. Jakarta : Jurn al Buletin Prisma.Todaro Michael dan

Smith Stephen. 2010. Pembangunan Ekonomi. Jilid I Edisi Kesembilan. Jakarta : Erlangga.

Sukirno, Sadono. 2010. Ekonomi Pembangun an. Jakarta : Kencana Prenada Media Group.

Sutawijaya, Adrian. 2004. Analisis Disparitas Pendapatan Antar Daerah danPotensi Relatif Secara Sektoral. Jakarta : STIE 